\title{
“MEMÓRIA DE FERRO”: Trajetória artística e produção estética de Eder Santos
}

\section{“MEMORIA DE FERRO": Artistic trajectory and aesthetic production of Eder Santos}

Thamara Venâncio de Almeida ${ }^{1}$ 


\section{Resumo}

Este estudo pretende abordar a trajetória artística e a produção estética de Eder Santos, privilegiando as obras que têm o vídeo como um dos suportes. Com uma produção e trajetória multifacetada, como videomaker, cineasta, publicitário e artista, essa análise privilegia a sua produção nesse último empreendimento. Partindo da sua participação com vídeos single channel em festivais de vídeo, em especial o Videobrasil, passaremos brevemente pela sua internacionalização, demonstrando algumas participações em festivais e em mostras de arte em museus estrangeiros, até concluir com a criação de videoinstalações que serviram para inserir o artista no circuito emergente das artes tradicionais aqui no Brasil, em um momento de novas perspectivas e profícua ampliação do mundo da arte contemporânea. No mais, as análises estéticas das obras de Santos nesse estudo privilegiam a temática da política da memória, que tem como recorrente um resgate histórico ao passado, em que intentamos apresentar possíveis eixos de leituras sob essa concepção.

Palavras-chave: Eder Santos; Videobrasil; arte contemporânea; videoarte; política da memória.

\section{Abstract}

This study intends to approach the artistic trajectory and aesthetic production of Eder Santos, privileging the works that have the video as one of the supports. With a multifaceted production and trajectory, as videomaker, filmmaker, publicity and artist, this analysis privileges its production in this last undertaking. Starting with its participation with single channel videos in video festivals, in particular Videobrasil, we will soon go through its internationalization, demonstrating some participation in festivals and art shows in foreign museums, until concluding with the creation of video installations that served to insert the artist in the emerging circuit of traditional arts here in Brasil, at a time of new perspectives and fruitful expansion of the world of contemporary art. Moreover, the aesthetic analyzes of the works of Santos in this study privilege the theme of the politics of memory, which has as a recurrent historical rescue to the past, in which we try to present possible axes of reading under this conception.

Keywords: Eder Santos; Videobrasil; contemporary art; video art; memory politics.

ISSN: 2175-2346

1 thamaravenancio@live.com 


\section{A fase experimental: manipulando as imagens}

Eder Santos, nascido em Belo Horizonte em 1960, é um videoartista brasileiro que muito cedo teve contato com o filme, o que fez considerar em sua trajetória artística as outras formas de arte que estavam emergindo. Com apenas 12 anos de idade, quando ainda cursava o Colégio Técnico da UFMG, junto com seu amigo Marcus Vinícius Araújo Nascimento, começou a estudar sobre roteiro e a tecer imagens utilizando o Super-8, suporte que experimentou até 1978. A passagem que marca a mudança de interesse do filme para o vídeo está ligada à história da filmagem de um roteiro. Para realizar o projeto, segundo Santos (2002), seu amigo Marcus Vinícius comprara uma câmera $16 \mathrm{~mm}$ Bolex e, logo depois, perto das filmagens, ganhou outra câmera, dessa vez de vídeo VHS portátil, que eles levaram também para as filmagens. Durante o processo, resolveram gravar tudo o que estava sendo filmado na 16 $\mathrm{mm}$ em vídeo e, segundo Eder Santos, quando foram revelar "do filme não saiu nada, mas do vídeo saiu tudo" (SANTOS, 2002, p. 431). Cativados pelo novo suporte, é então que surge a preferência e o interesse pela mídia videográfica.

Em 1979, Eder Santos ingressa na Escola de Belas Artes da UFMG, lugar em que desliza entre o interesse pelo cinema e a produção de desenhos e esculturas. Embora já trabalhasse com o vídeo e já houvesse experimentado o cinema antes, tendo inclusivo estagiado no Centro Audiovisual, Santos nunca concluiu a faculdade de Belas Artes, por um motivo curioso: foi reprovado duas vezes conseguintes em uma disciplina de Introdução ao Cinema. Foi na faculdade de Belas Artes que iniciou a produção de uma série de vídeos de artistas. A convite de Paulo Rossi, então diretor do Museu Mineiro de Belo Horizonte, da exposição de Márcio Sampaio "No limite do possivel - face a face", foi chamado para fazer um vídeo do artista para integrar a exposição. Fez outros vídeos de artistas, como os de Jeanne Louise Milde e de Celso Renato (SANTOS, 2010).

Afim de aperfeiçoarem as técnicas com a câmera de vídeo, Eder Santos e alguns conhecidos convidaram alguns especialistas de São Paulo para irem a Belo Horizonte ministrar um curso básico de vídeo no Palácio das Artes, que aconteceu na sala Humberto Mauro, em 1979 (SANTOS, 2002). A partir daí, cresceu o interesse de exploração da técnica videográfica, como relata:

Intrometemo-nos tanto no curso, que no final resolvemos nós mesmos dar cursos de vídeo e montamos uma empresa para oferecer isso. Dávamos aulas numa garagem. A maioria dos alunos eram pessoas que queriam aprender a programar, gravar da televisão, coisas simples. Durante o curso, fiz dois videopoemas chamados Cactus e Hipopótamo, com Alícia Penna e Sandra Penna, que é a minha mulher. (SANTOS, 2002: p.431)

Por residirem em uma cidade situada a margem dos principais polos produtores do Brasil, São Paulo e Rio de Janeiro, os entusiastas belorizontinos pensaram estar atrasados em relação à utilização dessa nova mídia, o que mostramos ao longo dessa dissertação que se tratava de um problema geral no Brasil, que só fora quebrado pelo interesse de exploração contínua do meio. No momento em que se depararam com a dificuldade comum, buscaram investigar por eles mesmos essa tecnologia re- 
lativamente recente, não só para a cidade, como também para o país. Com o intuito de fortificar e dar abertura a essa nova exploração, Eder Santos e Marcus Vinícius do Nascimento criaram a EMvídeo - "E" de Eder e "M" de Marcus -, produtora independente que atuou no auxílio e na produção de vídeo em Belo Horizonte para diversos setores (SANTOS, 2010). No início de 1980 já haviam comprado uma ilha industrial e começaram a participar de festivais de vídeo no Brasil, inscrevendo obras de caráter experimental. Em 1983, Eder Santos abandonou o curso de Belas Artes da UFMG e viria a se formar em 1984, ao concluir a graduação em Programação Visual que cursou pela Fundação Mineira de Arte Aleijadinho (FUMA) (SANTOS, 2010).

A questão do descentramento e muitos outros paradigmas contemporâneos podem ser vistos nas obras do artista aqui eleito para análise. No intuito de discorrer sobre as temáticas contemporâneas postas à prova nesse período de descobertas, com a máquina, com o corpo, com o passado e o presente, que marca essa geração, iremos discorrer por meio da análise estética de suas produções, explicitando a política da memória e o resgate histórico que o artista recorrentemente tem pretensão de evocar. Para isso, optamos por desenvolver nossa reflexão no âmbito da estética, e não mais dentro da tradição da arte autônoma da modernidade, enfatizando o exercício sensível da experiência do artista, "que não se desvincula das transformações materiais da sociedade, se desenvolvendo em continuidade com os processos da vida cotidiana" (BUENO, 2001, p. 81).

$\mathrm{Na}$ análise das obras de Santos, de caráter híbridas, principalmente pela escolha do suporte, recorreremos a visões de diferentes teóricos, críticos e historiadores de arte contemporânea, que vêm se debruçando sobre o estudo da arte atual. Muitos dos temas trabalhados atualmente, como a memória, o esquecimento, a temporalidade, o local versus o global, as ruínas, a cooperação, a segmentação, o passado sob o presente, e até mesmo a questão sobre o dispositivo, entre outros, serão apontados e desenvolvidos através das produções de Eder Santos.

A exploração se torna o modo de perceber a obra, fazendo assim com que a
experiência se dê no tempo, negando categorias pré-concebidas de espaço e de
tempo e se construindo a partir de ajustes múltiplos da memória tanto em rela-
ção ao esquecimento quanto em relação a posturas antecipatórias. O frágil, o
efêmero, o instável, o transitório, tornaram-se temas dominantes nas propostas
artísticas desta época. O tempo tornou-se não apenas um tema recorrente, mas
também a metodologia que define a própria natureza do trabalho de arte. Ver o
tempo, distorcê-lo, rasgá-lo, fazê-lo desaparecer, de acordo com Christine Buci-
-Gluckmann, foi um dos grandes sonhos artísticos do ocidente que não cessou de
fabricar máquinas de visão e de criar trajetórias que desestabilizassem o regime
de centramento postulado pelas leis da perspectiva linear. (CARVALHO, 2008,
p.41-42).

No entanto, para trabalharmos a trajetória do artista e as obras produzidas ao longo de sua carreira, partiremos de sua inserção nos locais em que ganhou notoriedade, que advém da participação em festivais de vídeo.

Ingressando em circuitos alternativos de exibição de vídeos, que emergiram no início dos anos 1980, Eder Santos passa a participar de forma recorrente desde 1984 em alguns deles, em especial o Festival Videobrasil, lugar em que constrói uma importante rede de relações ao conviver com respeitáveis agentes e ao receber di- 
versos prêmios. A sua trajetória é inapresentável em relação a sua construção como videoartista através desses festivais e mostras de vídeo. Utilizando um suporte contemporâneo em via de sistematização, Santos transpassa seu uso através de diversos interesses, ora em contato com o cinema, ora com as artes plásticas ou a literatura, mesclando diversas influências para composição de obras. O artista explora a linguagem do vídeo em suas diversas facetas, criando videoarte, mesmo sem saber do que se tratava na época.

Ainda na segunda edição do Festival Videobrasil, Santos participou da mostra competitiva com dois dos vídeos de artistas citados anteriormente, sendo um o vídeo da artista belga Jeanne Louise Milde (1984), em que capta fragmentos da vida e da obra da escultora, e o outro, o vídeo do artista plástico Márcio Sampaio, comentado mais acima. Os vídeos de Santos não levaram nenhum prêmio nesse ano, mas a sua participação no Videobrasil foi um pontapé inicial para o colocar em contato com a produção jovem efervescente da época. O artista conta em entrevista para a compilação do vídeo VB na TV (PGM1), editado pelo Videobrasil, que chegou a ir na primeira edição do festival em 1983, mas de tão cheio, não conseguiu entrar no auditório, tendo que assistir à distância e em pé.

Na edição seguinte, de 1985, Santos inscreveria dois videopoemas, "Cactus" e "Hipopótamo" - criados durante o curso de 1979, em que levara convidados de São Paulo a Belo Horizonte -; um vídeo de artista, em que documentou a obra do artista plástico Celso Renato, intitulado "Paracelso"; e ainda o seu primeiro trabalho de videoarte experimental, "Interferência" (1984), que definiu todo um caminho em sua produção.

No vídeo "Interferência" (1985), Santos registra diretamente da tela da TV uma exposição de cartões postais das artistas Inês Rabelo e Marlete Menezes, com uma câmera fotográfica. Ao se apropriar de imagens tiradas da mídia televisiva e transportando para a linguagem do vídeo, Santos, com seus ruídos, desconstruções e "interferências" na imagem, claramente faz uma crítica ao formato bem-acabado da televisão. Com o vídeo, ele se apropria de imagens de outra mídia e vice-versa e, além de deslocá-la e dispersá-la, trata-a de forma irônica. No entanto, ao explorar os "defeitos especiais" da imagem eletrônica, sobrepondo imagens e alterando as cores, Santos está explorando a estética do vídeo, em via de sistematização. Nas palavras de Eduardo de Jesus, "a obra de Santos trata das imagens, e é intensamente autorreferente", além do tema proposto em cada obra particular, ela "diz também da própria natureza das imagens na contemporaneidade, especialmente das imagens do vídeo" (2010, p. 4).

Não é por menos que esse vídeo tenha sido um marco de sua carreira, tendo ganhado o prêmio de melhor vídeo experimental na terceira edição do Festival Videobrasil. Solange Farkas, em depoimento sobre o artista para o VB na TV, diz que, principalmente no começo, Eder Santos estava fora do padrão. Com isso, tomamos consciência de como os vídeos de Santos destoavam dos demais que eram exibidos pelo festival, o que acabou incitando o entendimento para aquele tipo de produção, que poucos conheciam ou entendiam na época. Somente mais tarde o artista discerniria de que estava produzindo videoarte, fora dos padrões reproduzidos na época. 


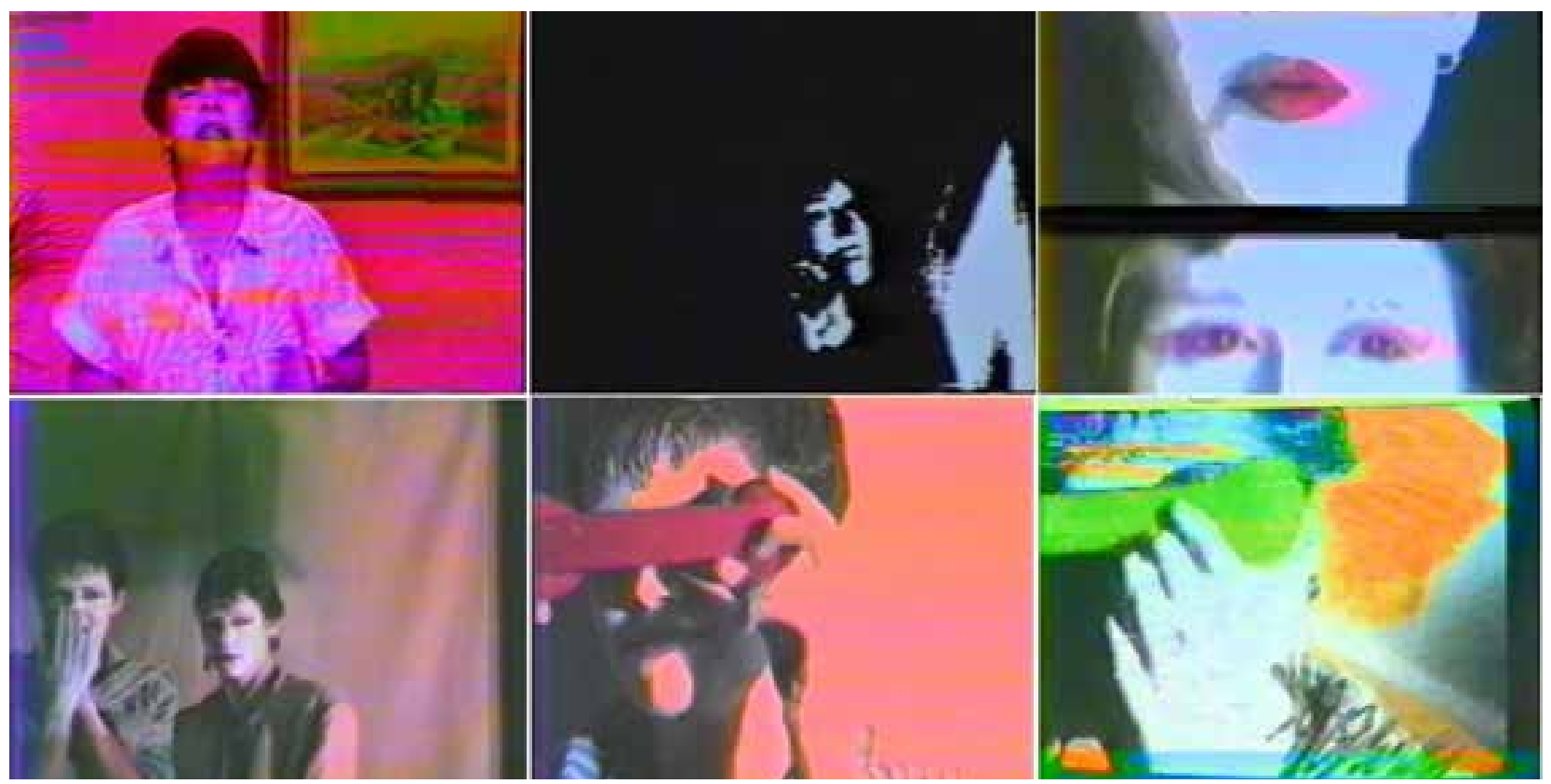

Figura 01 - Frames do vídeo "Interferência", Eder Santos, 1985.

Fonte: Print do vídeo VB na TV https://vimeo.com/80087344

Em 1986, Santos aparece somente com um vídeo na mostra competitiva do Videobrasil, que trata da produção de lançamento da grife Câmbio Negro de Belo Horizonte. Segundo o site do Videobrasil, o vídeo mescla imagens de modelos nas ruas com cenas do desfile e é um registro histórico da moda em 1986. O vídeo deve se tratar de um trabalho publicitário autoral feito pela sua produtora.

No ano seguinte, o artista expande sua participação em outros festivais. Participa do terceiro Rio Cine Festival com duas obras, "Europa em cinco minutos" (1986) e "UAKTI" (1987), ganhando o Prêmio Especial do Júri com a primeira e o prêmio Sol de Ouro com a segunda. Com "UAKTI", participa ainda do Festival Videobrasil e do Fest Rio, levando dois prêmios do primeiro festival, Melhor Fotografia e Melhor Som, e o Tucano de Prata do Fest Rio. Em 1988, UAKTI participaria ainda do Festival del Cine de Cuba, no qual ganhou o prêmio Casa de las Américas.

A videoarte, em sua grande maioria, segue um padrão colaborativo de criação, semelhante ao da produção de um filme, mas em escala menor. Em uma entrevista cedida ao jornal O Estado de S. Paulo em 13 de março de 1996 para Gabriel Bastos Junior, Santos fala do incômodo que tinha em relação a artistas plásticos trabalharem sozinhos, e completa: "quando você trabalha com vídeo tem de partir do princípio que é um trabalho em equipe" (JUNIOR, 1996).

Após UAKTI, Santos, juntamente com Marcus Vinícius e Lucas Bambozzi, criaram o vídeo "Mentiras e Humilhações" (1988), obra que seria retrabalhada mais tarde como videoinstalação. $O$ vídeo, de caráter espectral, mistura linguagem poética e imagens em super-8, relembrando a memória e seus fantasmas. As imagens da casa e seus respectivos cômodos são, aos poucos, preenchidos com uma luz etérea, sobrepostas em aparições de imagens que remetem ao passado. Tais imagens recorrem a visões de memória que o artista tem pretensão de evocar, implícitas nas palavras faladas de uma senhora em voz off, recitando o poema "Liquidação" de Carlos Drummond de Andrade: 
A casa foi vendida com todas as lembranças / todos os móveis todos os pesadelos / todos os pecados / cometidos ou em via de cometer / a casa foi vendida com seu bater de portas / seu vento encanado sua / vista do mundo / seus imponderáveis / por vinte, vinte contos. (ANDRADE, 1993, p. 503).

Apresenta um retrato da decadência de famílias, mostrando em vez de um ritmo alegre de uma família numerosa, com suas festas, recepções e reuniões, a vida em slow-motion, onde tudo cheira a passado. Antes do poema ser recitado, prevalece a música de um piano tocando, com barulhos concomitantes de talheres e pratos batendo, copos sendo preenchidos com algum líquido, entre outros sons, o que nos remete a uma pessoa realizando alguma refeição do dia. $O$ vídeo inicia com cenas externas da casa, passando posteriormente para seu interior, local em que os "fantasmas" se sobressaem. As imagens vão sendo cada vez mais tomadas pela luz espectral. A perda desse local físico é elucidada pela planta da casa, que é apresentada em uma das cenas. A temporalidade nessa obra é singular, uma vez que demonstra a degradação de imagens que remetem a um local concreto (físico), sendo corroídas pela ação do tempo (etéreo). Uma cena que ilustra essa passagem do tempo, é quando a câmera enquadra em contra-plongée uma parte superior externa da casa, captando parte do céu com nuvens que passam, aludindo a uma metáfora do tempo, volátil, efêmero, intransigente. Acerca dessas insinuações de mudanças nas percepções do tempo e do espaço, o historiador e crítico de arte Andreas Huyssen trata-a como sendo característica do nosso momento histórico. Segundo o autor:

A memória como obsedante e sombria, e não plenamente transparente, a sombra da memória escurecendo um presente predominantemente esquecido, os locais de violência e os espaços de esquecimento, tudo isso, a esta altura, tornou-se central para um discurso político e cultural cada vez mais amplo em todo o mundo, tanto nas artes quanto no campo do ativismo dos direitos humanos. (HUYSSEN, 2014, p. 57).

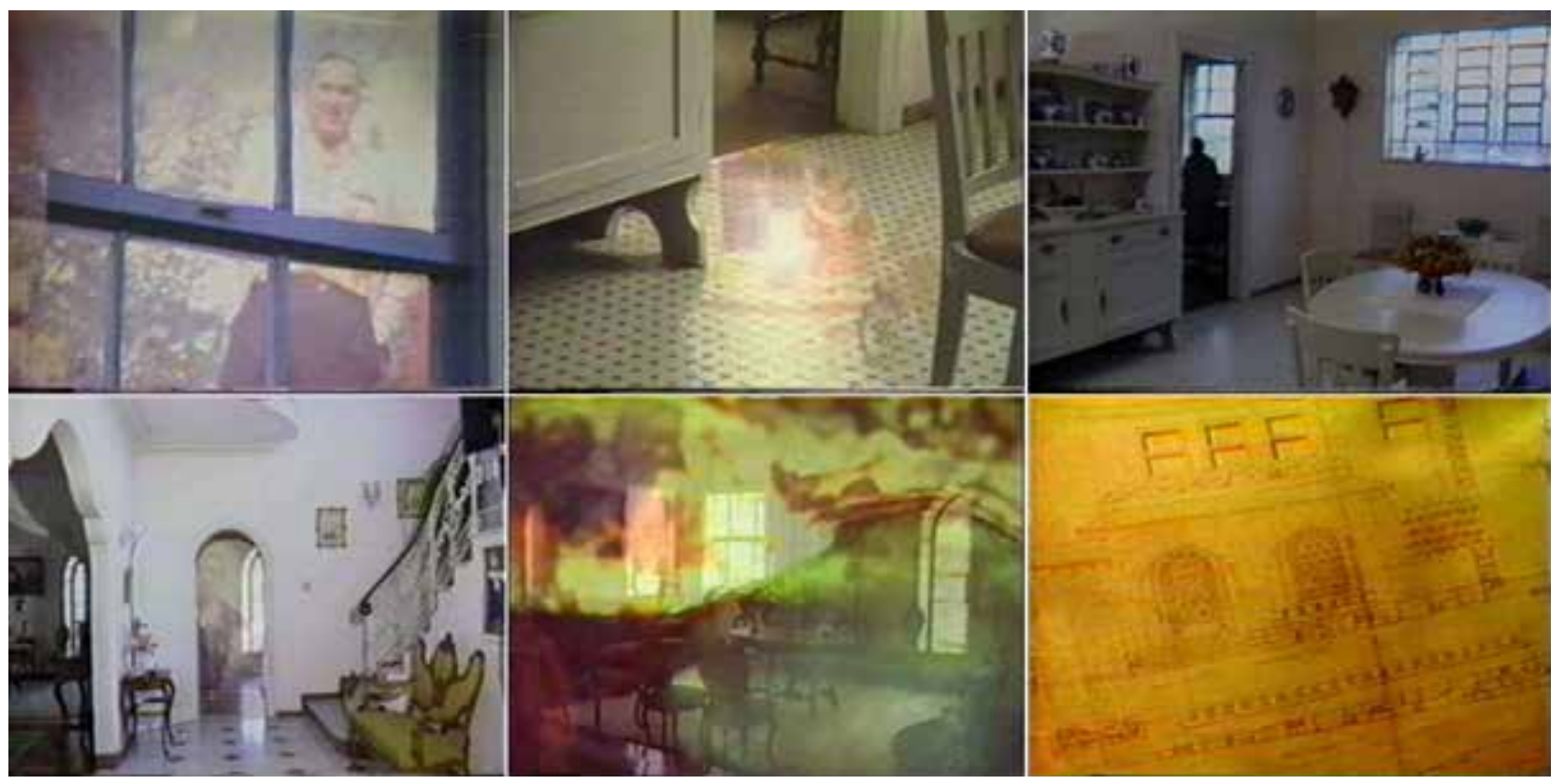

Figura 02 - Frames do vídeo "Mentiras e Humilhações", Eder Santos, 1988.

Fonte: Print do vídeo https://vimeo.com/148266002 
A hibridização entre vídeo e poesia, que essa obra apresenta, de acordo com Arlindo Machado (1997) é uma das conquistas mais interessantes da videoarte, em que se recupera o texto verbal inserindo-o no contexto da imagem, descobrindo assim novas relações significantes entre códigos aparentemente distintos. No Brasil, foram os concretistas e seus herdeiros que anteriormente mais investigaram essas relações, tendo a videoarte herdado esse legado (MACHADO, 1997).

Ao mesclar lembranças do passado da casa, com o presente, Santos está materializando algo que talvez não exista mais, mas que de alguma forma ficou marcado em sua memória, e dessa forma se obstina a seguir vivendo, apesar de que possa não mais subsistir materialmente. Para o crítico e historiador de arte Hal Foster (2004), a sombra que paira sobre a arte contemporânea é mais literalmente espectral ou fantasmagórica, que "configura tanto a um morto que regressa como a um fantasma cujo esperado retorno se repita uma e outra vez" ${ }^{1}$ (2004, p. 130), ou em tais obras que se configura alguma perda de algo que não mais existe, ou procura recordar por meio de objetos ou signos antigos o espírito de um passado social, assim como Eder Santos evoca em "Mentiras e Humilhações". O nostálgico vídeo ganhou o prêmio de "Melhor Vídeo Experimental" no 5 Rio Cine Festival de 1989, e outros dois prêmios no 6 Festival Videobrasil, de "Melhor Direção" e "Melhor Fotografia", em 1988.

A partir do momento em que Santos adentra de forma efetiva nesse universo de festivais de vídeo, sendo reconhecido por eles pelos prêmios, conseguimos traçar o seu amadurecimento percorrendo as suas produções, que se deslocam além da tela do monitor de televisão, em seu formato single channel ${ }^{2}$. O vídeo Rito \& Expressão (1989), que foi criado inicialmente para esse formato, acaba extravasando seus limites ao participar do 7을 Festival Videobrasil. A obra single channel foi aceita para participar da mostra competitiva na categoria "videoarte", no entanto, em virtude de um convite feito pelos organizadores do festival, acabou se transformando na videoinstalação "Oremos" (1989).

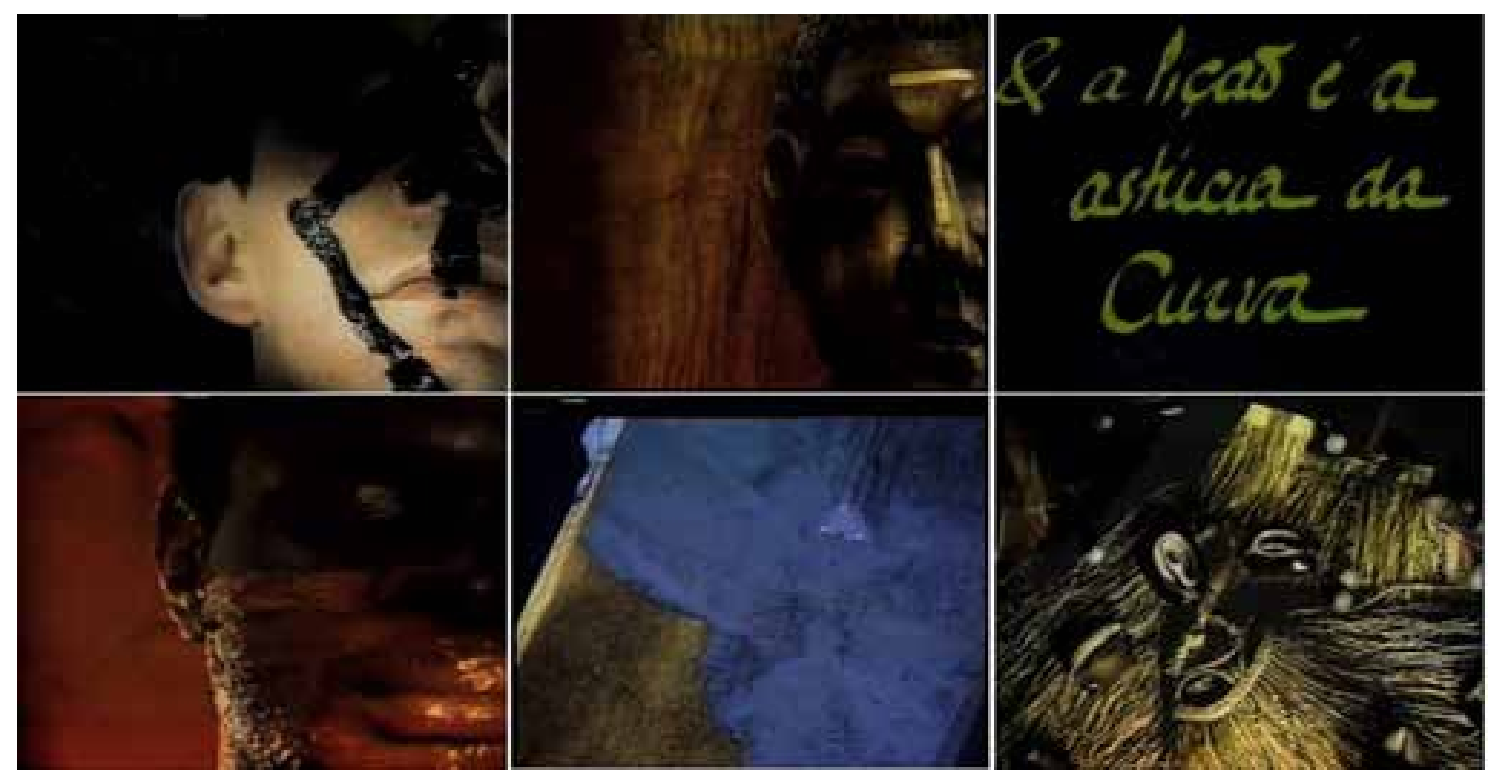

Figura 03 - Frame do vídeo "Rito \& Expressão", Eder Santos, 1989 Fonte: Print do vídeo https://vimeo.com/album/2630179/video/85397318

1 Original: "[...] configura tanto a un muerto que regresa como a un fantasma cuyo esperado retorno se repite una y otra vez." (FOSTER, 2004, p.130) 2 Refere-se a obras que envolvem uma única fonte eletrônica (VHS, U-matic, DVD, etc) apresentada num dispositivo de reprodução e exibida utilizando um único modo de visualização (tal como um monitor ou projeção). 
No vídeo single channel, com base na tese "O negro no Barroco Mineiro: o caso da Igreja do Rosário de Ouro Preto" de Cristina Ávila e Maria do Carmo Andrade Gomes, publicada pela Revista do Departamento de História da UFMG em 6 de julho de 1988, o artista concebe a busca por resgatar um momento perdido na história, reconstruindo um ato do passado. Na tese, as autoras enfatizam a mescla da cultura negra com a católica através da construção dessa igreja. Segundo as autoras:

Os negros não deixaram de lado as expressões que lhes eram mais próprias - o ritmo, a música e a dança, que transformaram festas e procissões religiosas em manifestações onde o sagrado e o profano se contundem e se integram, como são exemplos os reisados, congados, batuques e tamborzeiros. No aspecto devocional, fundiu elementos da sua própria cultura à religião dominante que lhe foi imposta, sincretizando santos e virgens. (ÁVILA; GOMES, 1988, p. 75).

A evocação da história cultural da igreja, um edifício Barroco construído no séc. XVII, remete a um passado cultural e sociológico específico, pertencente à cultura negra africana. No vídeo, Santos recorre ao primitivo utilizando de materiais usados na construção, como terra, madeira, pedra, barro e tinta, enquanto um poema de Affonso Ávila, que fala das curvas do barroco, é ora descrito em imagem (ver terceiro frame da Figura 35). O humano, o social e o cultural encontram-se no vestuário africano e em alguns objetos rituais, a exemplo dos búzios e contas (sementes usadas na confecção de colares, entre outros). Ao se apropriar de tais materiais, objetos e vestimentas próprias da cultura africana, Santos está naturalmente memorando um passado africano de rituais e costumes praticamente extintos aqui no Brasil. Além de levantar questões históricas de um passado colonial, o videoartista evoca um retorno a uma sociedade escravocrata, de uma cultura submissa que deixou muitos vestígios dela em nosso país. Por mais que a igreja ainda exista, o gesto de reconstruir, de reencenar algo do passado, remete a uma vontade de resgatar algo perdido na história social, servindo também de fonte de conhecimento, no sentido de que muitos desconhecem tal fato histórico. Com isso, Eder Santos enaltece a influência dos negros, em dominação europeia, na construção de nosso passado, em que muitos historiadores tentaram apagar essa influência. Nessa obra é levantado o binário corriqueiro: memória versus esquecimento. Huyssen pontua que "as diferentes formas de esquecimento são parte da memória" e "lembrar significa ler vestígios; requer imaginação, atenção do olhar, construção" (2014, p. 68).

Ao reconhecer essa obra como um resgate de um fato histórico do passado, que fora camuflado por mitos, afim de apagar as influências culturais dos negros, 0 artista cria um lampejo de reconhecimento no "agora", influenciando o observador a pensar de maneiras criticamente novas na política da memória. Os temas trabalhados nas obras de Santos estão intrinsicamente ligados às influências recebidas pelo local em que vive, uma região mineira de forte cultura barroca. Raramente suas fontes de inspirações se estendem para além da região em que reside. $O$ artista recorre frequentemente a poetas e historiadores conterrâneos. Podemos elucidar de exemplo os já citados, Carlos Drummond de Andrade, que é natural de Itabira e morou em Belo Horizonte; e Cristina e Affonso Ávila ${ }^{3}$, naturais de Belo Horizonte. Com isso ele retrabalha o local em virtude do global, uma vez que o meio (o vídeo) o qual utiliza

30 escritor Affonso Ávila é pai da historiadora de arte Cristina Ávila. 
é globalizado, mas as suas temáticas se voltam para o território em que vive/reside.

No espaço do "redondo" no MIS, por meio de andaimes, foi construída a videoinstalação "Oremos", simulação de uma catedral barroca mineira. O vídeo "Rito \& Expressão" foi projetado em oito monitores (que representavam os passos da Paixão de Cristo), situados quatro de cada lado (como na Figura 04). Três telões foram colocados no ambiente: um tomou lugar do "altar-mor", local da igreja em que se situa a imagem do santo que a representa; e outros dois foram colocados acima dos bancos, fazendo alusão ao teto pintado das igrejas, que serviam para prolongar sua estrutura em direção aos céus. Nessas telas, o artista projetou imagens de outro vídeo criado para a obra. O vídeo é uma mescla de nuvens em movimento com imagens de anjos e da arquitetura da própria Igreja do Rosário. As nuvens e os anjos fazem analogia ao teto de uma Igreja Barroca. No catálogo do 7은 Videobrasil é apresentado o seguinte ensaio/poema do próprio artista, referente a obra:

Aos deuses, os sentimentos / Aos humanos, as imagens / É com profundo pensar / Que anunciamos a cerimônia em vídeo / De pedra, lamas e flores / De batimentos e slows / Como que tomadas, as pessoas se ligam / E rezam ao som dos monitores / Sentados na igreja voltamo-nos para cima / E com o pensar oramos a Deus: / A Deus que nos deu as nuvens e os telões / os vídeos projetores a cores. / A Deus que nos deu o telão maior. / A Deus que nos deu sintonia fina. / E por carregamento (loading) vemos os / Ritos e Expressão. / E joga na bandeira / ô / Oi joga na bandeira / ô / Oi joga fogueira / ô / Oi roda Pomba Gira / ô / Oi pega na bandeira / ô / Atira a primeira pedra / Aquele que já passou / Oi roda a roda girou / Põe fogo na roda oi / Oi joga na fogueira ô / Arrebenta assim o Rosário / E por carregamento (loading) / Rito e Expressão. (VII FESTIVAL FOTOPTICA VIDEOBRASIL, 1989, p. 25).

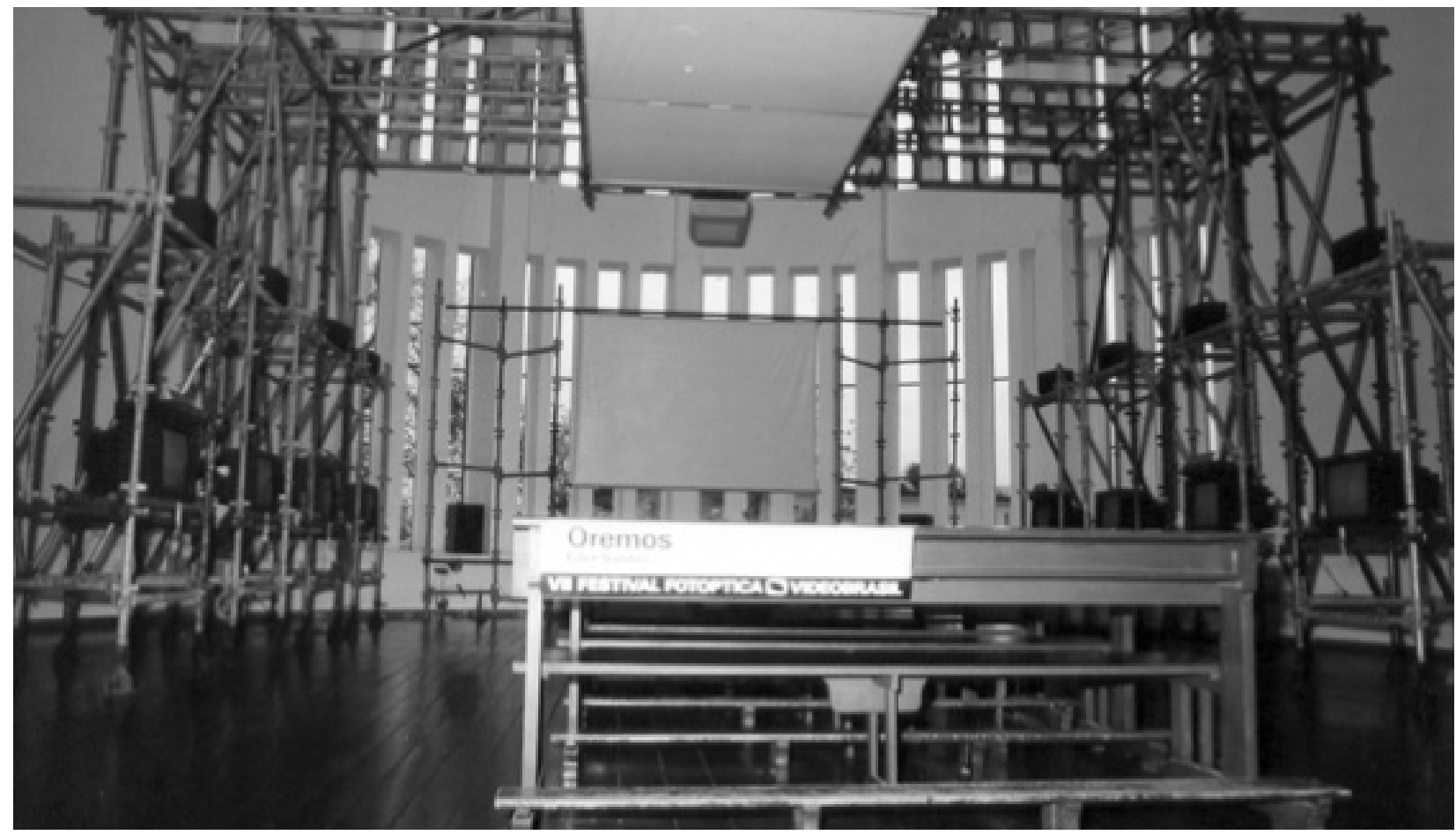

Figura 04 - Videoinstalação "Oremos", Eder Santos, 1989.

Fonte: Site Videobrasil http://site.videobrasil.org.br/festival/arquivo/festival/programa/1402077 
A videoinstalação de Santos demarca um momento de expansão do Festival Videobrasil, trazendo para o espaço expositivo uma grande plataforma para imersão do espectador, e pode ser considerada a primeira no festival a utilizar de projetores de vídeo em sua montagem. Segundo Roberto Moreira S. Cruz (2010), o artista lançou mão de três projetores modelo Sony CRT VPH 1000, que incidiam imagens nos telões, recriando simbolicamente o ambiente de uma capela. Sobre a construção da obra, Eder Santos relata:

A gente fez no estúdio. O roteiro foi chegando nisso. Acabou vindo um pessoal de um centro espírita que deu um monte de coisas, todos os búzios... No final, eu montei a igreja com os bancos do centro espírita, foi uma confusão. Depois, a última cena era uma Folia de Reis - gravada no estúdio - que misturava com capoeira... e acabou nesse vídeo. (SANTOS, 2010, p. 16).

Essa videoinstalação coloca em pauta a questão do dispositivo e da experiência do público. O conceito de dispositivo foi primeiramente desenvolvido em relação ao cinema, contaminando depois outros campos teóricos, se devendo "ao fato de que as obras de arte e as imagens não se apresentam mais necessariamente sob a forma de objetos, uma vez que se 'desmaterializam', e se 'dispersam' em articulações conceituais, ambientais e interativas" (PARENTE, 2008, p. 51-52). Alguns autores propõem em pensar os dispositivos imagéticos na atualidade como experiência que constitui a obra, e segundo Victa de Carvalho:

Se a imagem é sempre uma experiência, se não existe arte sem a experiência do sensível, é preciso então compreender o que está em jogo quando nos referimos a uma arte do virtual. Apenas pensando o virtual como uma categoria estética e não como uma descoberta tecnológica, é que podemos analisar as produções contemporâneas como produtoras de novas subjetividades. $\mathrm{O}$ real não se opõe ao virtual, mas aos ideais de verdade que ele expressa. Desse modo, uma arte do virtual seria uma arte de constantes construções e desconstruções, de permanentes atualizações e virtualizações, onde a obra acontece em um processo temporal, sendo o tempo o operador que coloca em crise a verdade do mundo. O tempo como mudança, como novo. (CARVALHO, 2008, p. 40).

Com isso, são desenvolvidas noções de dispositivo expandido que engendram "uma rede de agenciamentos de elementos heterogêneos, relativos a um determinado momento histórico, onde a tecnologia é uma de suas faces, junto com a arquitetura, a cognição, os afetos e discursos" (CARVALHO, 2008, p. 40). Segundo alguns autores, a exemplo de Anne-Marie Duguet (2002), foi a videoarte que provocou esse processo de desterritorialização do cinema, fazendo-o passar a uma reformulação de seu dispositivo, levando-o a pensar as passagens "entre imagens". O vídeo seria o dispositivo privilegiado capaz de levar ao extremo a experiência com a imagem, criando novas temporalidades e promovendo uma indistinção dos corpos - do observador e da imagem (CARVALHO, 2008). Nessa concepção, e a exemplo da videoinstalação apresentada, o dispositivo criado deve ser acionado, senão a obra permanece em puro estado de virtualidade.

Dessa forma, o dispositivo expandido adentra inúmeras possibilidades, acerca da sensação causada pelo espectador e, retornando à videoinstalação de Santos, era de um constante movimento, devido à transitoriedade das imagens e dos efeitos que as curvas do barroco, em constante rotação, causavam. 
Sentados no banco da "Igreja Eletrônica", os "fiéis" poderiam contemplar as imagens de forma aleatória, sem uma narrativa predeterminada, seja dos televisores situados nas laterais, ou do teto e do altar-mor, e poderiam assim rezar ao som dos monitores, assim como proposto no ensaio/poema criado pelo artista, apresentado acima. Em "Oremos", o ambiente instalativo mobiliza o visitante para novas compreensões da imagem em diferentes modalidades temporais e marca uma passagem de expansão para o Festival Videobrasil, sobre o qual Solange Farkas relata:

A relação com as artes visuais foi uma coisa que foi acontecendo processualmente, com uma perspectiva de estrutura de produção bem maior, que é a passagem do cubo preto para o cubo branco, que é esse lugar do vídeo que sai dessa sala escura e começa a se relacionar com o espaço arquitetônico, com outras linguagens, e que precisa de um lugar apropriado, ou seja, espaço de galeria, continuamos claro, sempre com o cubo preto ali do lado, óbvio, mas esse lugar mais híbrido. (FARKAS, transcrição do vídeo DEPOIMENTO | 30 ANOS | SOLANGE FARKAS $^{4}$ )

Por coincidência, a virada para a década de 1990 marca uma mudança na trajetória artística de Eder Santos. Imerso no mundo das imagens como criador perspicaz, o artista, mesmo com uma produção madura e repleta de significados - que percebemos ao percorrer suas obras inicias -, tinha pouca consciência do potencial artístico desses vídeos, que começou a vislumbrar ao construir essa primeira videoinstalação em 1989.

\section{Rede de contatos internacionais}

O início da década de 1990 para a trajetória de Eder Santos pode ser contada de várias perspectivas que serviram para impulsionar sua carreira. Não sabemos ao certo se foi no ano de 1989 ou 1990 que a artista nova yorkina Joan Logue, em virtude do Festival de Inverno da UFMG, veio ao Brasil dar uma oficina de vídeo no festival. Face ao problema de não terem equipamentos de edição para terminarem a oficina nas dependências da universidade, solicitaram o término ao pessoal da produtora EMvídeo. Na época, Santos era o editor, e foi ele o responsável por ajudar Logue a editar os vídeos dos alunos (SANTOS, 2010).

Segundo Santos (2010), a artista ficou por lá uma semana, fato que propiciou conhecê-la melhor, possibilitando que ela apresentasse alguns de seus vídeos a ele. Com isso, Santos mostrou a Logue os vídeos mais maduros que havia feito até o momento, "Europa em 5 minutos", "UAKTI", "Mentiras e Humilhações" e "Rito \& Expressão" (SANTOS, 2010). Sobre o episódio, o artista relata:

\footnotetext{
Na hora que ela terminou de ver os vídeos, ela estava chorando, e disse: "Você fez um vídeo que eu sempre quis fazer na minha vida. Você vai para Nova York, e eu vou te apresentar para todos os videoartistas". E eu nem sabia que eu fazia isso: videoarte. Eu já estava fazendo, tinha quatro vídeos. Daí a 15 dias, eu fui para Nova York. Fiquei 15 dias na casa dela, no Soho, e conheci todo mundo, toda essa gente que trabalha com videoarte. Conheci muita gente. Aí eu deixei meus vídeos lá na distribuidora, Electronic Arts Intermix, (www.eai.org), que já distribuía a Joan Logue. E um ano depois eles resolveram me distribuir. (SANTOS, 2010: p.23)
}

4 Link de acesso para o vídeo: https://vimeo.com/album/2630179/video/87182638 
Dentre os videoartistas para os quais Logue o apresentou em Nova York, estava o pai da videoarte, Nam June Paik, então vizinho da artista, que morava no mesmo prédio, no Soho em Nova York. Além do contato com a distribuidora EAI (Electronic Arts Intermix), que até a atualidade distribui suas obras, sendo o único artista brasileiro presente em seu catálogo, Logue apresentou outras figuras importantes que abriram portas para a carreira internacional de Santos. Uma das pessoas com a qual fez contato através dela foi Barbara London, então curadora associada ao Departamento de Mídia e Arte da Performance do MoMA (Museum of Modern Art) de Nova York, amizade que mais tarde lhe renderia o convite para expor em uma mostra coletiva no museu (SANTOS, 2010).

Ainda em 1990, Santos participa de alguns festivais. No 8 o Festival Videobrasil, em que apresenta "Não vou à África porque tenho plantão" (1990), ganha o prêmio especial de viagem a Montbeliárd ${ }^{5}$. Já no Festival de Vídeo de Canela, do Rio Grande do Sul, exibe "Rito \& Expressão" e recebe o prêmio de Melhor Vídeo Experimental. Participa, ainda nesse ano, da exposição coletiva Arizona Media Arts Center, em Tucson, EUA. Durante o 8 ${ }^{a}$ Festival Videobrasil, Santos é chamado por um dos convidados internacionais presente no evento, o holandês Tom Van Vliet, para participar da 9ª edição do World Wide Video Festival, em Haia, na Holanda, com o vídeo "Não vou à África porque tenho plantão".

Através do prêmio concedido a Santos pelo Videobrasil, em 1990, no qual ganhou uma viagem para Montbéliard na França, proporcionou ao artista o contato com novas tecnologias mais avançadas no Centre International de Création Vidéo. O evento realizado em junho de 1991, com um mês de duração, influenciou Santos a criar "Essa coisa nervosa" (1991) ao retornar ao Brasil. O vídeo é o segundo da trilogia que começou com "Não vou à África porque tenho plantão", e terminaria com o longa "Enredando as pessoas" (1995). Segundo o site EAI, em "Essa coisa Nervosa":

[...] Santos questiona como percebemos e recebemos informações através da mídia. Santos escreve: "Perdidos em nossas criações, devemos usar meios artificiais, como jornais e outras mídias, para simular o conhecimento do que está ao nosso redor, criando heróis, cidades, personagens, ícones e monumentos, o resultado é esta imagem nervosa, essa imagem que não para, este diálogo rápido, esta leitura dinâmica e superficial da essência do ser humano". Uma trilha sonora de condução propulsa o espectador através de uma frenética paisagem transcultural ${ }^{6}$. (Descrição da obra no site $\mathrm{EAI}^{7}$ ).

No MoMA, em 1992, esse mesmo vídeo integrou a coletiva "Committed Visions", feito a convite da curadora Bárbara London. Segundo o comunicado de imprensa do museu, a obra de Santos "examina os estratos hierárquicos e rituais na cultura brasileira" (PRESS RELEASE MOMA, 1992, p.01). Além de Santos, participaram mais sete videoartistas: Rhonda Abrams (canadense), Breda Beban (sérvia), Nancy Buchanan (americana), Péter Forgács (húngaro), Hrvoje Horvati'c (tcheco), Zacharias Kunuk (canadense) e Rea Tajiri (americana).

5 Prêmio de residência artística que havia sido iniciado em 1989 no Festival, no qual Sandra Kogut foi a primeira contemplada.

6 Tradução livre da autora, original: "[...] Santos questions the ways we perceive and receive information through the media. Santos writes: "Lost in our creations, we must use artificial means, such as newspapers and other media to simulate knowledge of what is around us. In doing so, we create heroes, cities, characters, icons and monuments. The result is this nervous thing, this image that doesn't stop, this quick dialogue, this dynamic and superficial reading of the essence of the human being". A driving soundtrack propels the viewer through a frenetic trans-cultural landscape."

7 Link de acesso: https://www.eai.org/titles/essa-coisa-nervosa 
Ainda em 1991, segundo cronologia de eventos apresentada em seu livro depoimento organizado por Marília Andrés Ribeiro (2010), as obras de Santos teriam integrado outras duas mostras coletivas nos Estados Unidos, a saber: Brazilian Videos, que aconteceu em Berkeley, na Universidade da Califórnia; e New Artists from EAl, Anthology Films Archive, em Nova lorque. As premiações e participações a partir de então se tornam frequentes, e optamos por ressaltar apenas as mais relevantes para o estudo.

A primeira obra comissionada pelo Videobrasil, em 1992, é uma videoinstalação de Santos, "The Desert in My Mind", em que projeta imagens captadas do deserto do Vale da Morte (Death Valley), na Califórnia (EUA). De acordo com reportagem feita por Antonio Gonçalves Filho (1992), do jornal Folha de S. Paulo, a escolha pelo artista de filmar o deserto veio de um sonho místico, enquanto sobrevoava o México, em que uma voz anunciava o porquê seu nome ser quase um anagrama de "deserto". Meses depois, o artista teria partido para o deserto californiano afim de gravar as imagens, inspiradas no filme "Zabriskie Point" (1970) de Michelangelo Antonioni - cineasta ao qual Santos sempre manifestou admiração - que também teve como cenário o mesmo deserto. Fugindo da abordagem onírica exposta pelo jornal, Santos expõe ao Videobrasil: "Os americanos viviam me falando da nossa floresta, então resolvi conhecer o deserto deles" (VIDEOBRASIL; SESC SP, 2015, p. 117).

As imagens gravadas no deserto com a sua equipe se transformaram na videoinstalação "The Desert in My Mind", que chamou a atenção dos jornais pelo alto valor de produção. Segundo a reportagem de Filho (1992), custou aproximadamente 70 mil dólares, ou cerca de 480 milhões de cruzeiros. Segundo o site do Videobrasil, a videoinstalação ocupou um espaço de $90 \mathrm{~m}^{2}$, em que o artista simulou um deserto. Santos teria usado 15 toneladas de areia, embora tivesse, inicialmente, a ideia de utilizar pedras de verdade, afim de simular as montanhas de Death Valley, fato que não ocorreu (FILHO, 1992). No ambiente instalativo, as cenas captadas são geradas por vídeo-disco ${ }^{8}$, através de oito canais sincronizados por computador, e projetadas sobre as areias, que simulam as dunas do deserto. Um fator inovador da videoinstalação, é a mudança climática que foi pensada pelo artista, afim de proporcionar ao público uma maior imersão no ambiente, que tende a promover a experiência de realmente estar em um deserto. As temperaturas são manipuladas por ar-condicionado, simulando o clima do deserto, onde as temperaturas tendem a ser altas durante o dia, indo até $48^{\circ} \mathrm{C}$, e baixas durante a noite, chegando a cair até $4 \stackrel{\circ}{ } \mathrm{C}$. O projeto do artista pode ser visto na Figura 05, abaixo:

8 Disco no qual estão armazenadas imagens que são projetadas através de aparelho eletrônico apropriado. Geralmente os aparelhos são situados no teto e se movimentam, fazendo com que a imagem se locomova. 


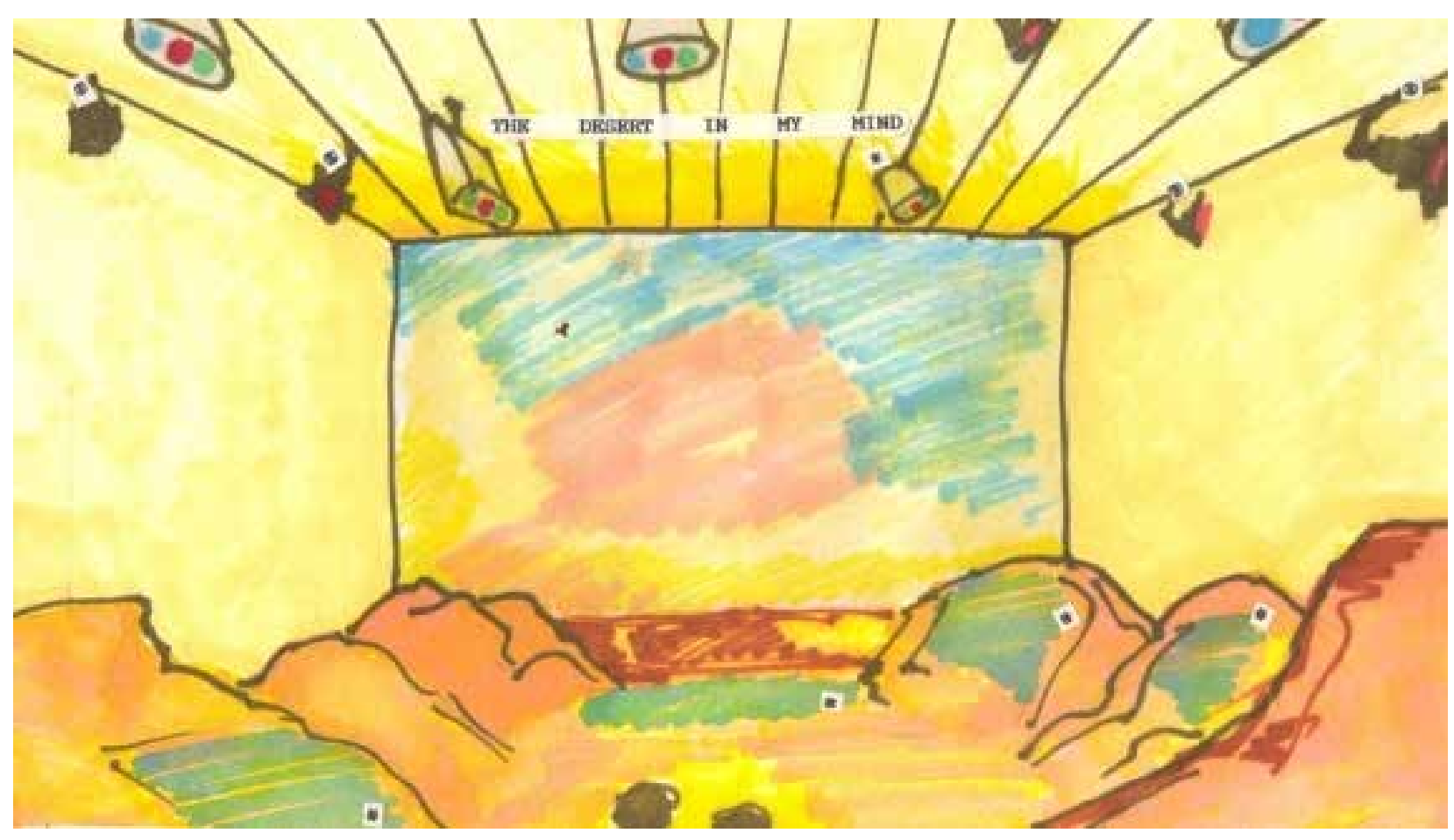

Figura 05 - Desenho-projeto "The Desert in My Mind", Eder Santos, 1992. Fonte: Site Videobrasil http://site.videobrasil.org.br/acervo/obras/obra/96126

A música original criada para a videoinstalação foi novamente uma parceria com Paulo Santos, do grupo musical UAKTI, e a trilha sonora feita por Stephen Vitiello ${ }^{9}$. Ao projetar as imagens sob as dunas de areia, Santos cria um ambiente virtual que conta com a participação do espectador, promovendo inúmeras sensações. São imagens de serpentes no deserto, temperatura atingindo seus picos mais altos, causando espantos, reflexos da lua durante a noite, que promovia um clima mais apaziguador e romântico. Segundo Arlindo Machado, na videoinstalação:

[...] os espectadores deviam caminhar sobre as imagens, com toda a carga semântica desmistificadora que pode existir no ato de pisar as imagens. Não satisfeito com isso, Santos introduz ainda manchas de luz pulsantes sobre a superfície da tela, ruídos visuais simulando os arranhões característicos dos velhos filmes cinematográficos, compromete a estabilidade da imagem através de interferências sobre o sinal de controle vertical ou através de uma câmera "tremida", que lembra os exercícios ingênuos dos amadores. (MACHADO, 2007, p. 28).

Segundo Filho (1992), outras imagens projetadas também foram muito marcantes, principalmente aquelas que Santos captara do Devil's Golf Course, local do deserto que antes havia sido coberto pelo lago Manly, e que após ter sido evaporado, restou apenas sal e minerais que foram dissolvidos pela água e formaram "esculturas" naturais. Comenta também que "a câmera parece seguir os passos de um demônio, atormentado pela aridez do deserto e tentando não tropeçar na tradição narrativa do cinema" (FILHO, 1992). 


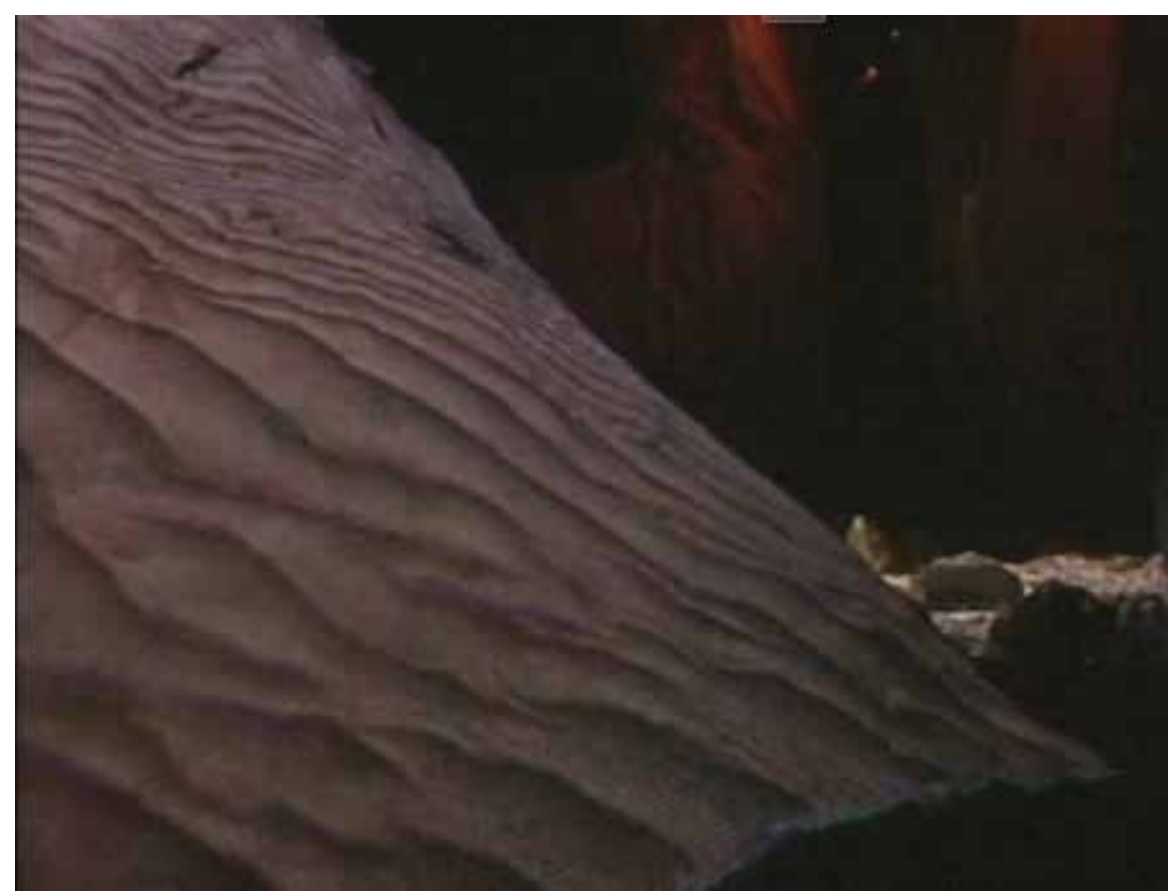

Figura 06 - Fotografia da videoinstalação "The Desert in My Mind", Eder Santos, 1992. Fonte: Print do vídeo VB na TV PGM3 https://vimeo.com/80612655

Das paisagens de "ruínas" naturais captadas do Devil's Golf Course, Santos involuntariamente retoma questões da degradação do meio ambiente causado pela ação do tempo e questões climáticas. As ruínas naturais, apresentadas por essas imagens, podem ser indicadas como referentes às ruínas arquitetônicas que são trabalhadas por artistas contemporâneos como temática, que exploram os restos e fragmentos de sociedades passadas. Segundo o restaurador Márcio Anacleto de Sousa Júnior, "as ruínas possuem também uma dimensão onírica porque são espaços para a fantasia e a especulação imaginativa, um convite à arte de construir ou reconstruir mentalmente" (2017, p. 136), uma definição que beira a intensão do artista ao construir a obra, em que profere: "Eu também caminho na direção daquele deserto que existe dentro de todo ser humano - o deserto das miragens e imagens que vemos em nossos sonhos $^{\prime 10}$. Com isso, o artista combina um ambiente de realidade virtual criado por ele, com a capacidade criativa e imaginativa do visitante, induzindo-o não só a entrar em um local fantasioso, mas fazendo com que também se remetam aos sonhos e devaneios pessoais. Mescla assim o virtual com o onírico, em um simulacro que mimoseia a aridez do deserto. Por meio dessa obra, Santos ganhou o prêmio de melhor instalação do ano, pela Associação Paulista de Críticos de Arte (APCA), em 1993.

Devido ao grande destaque dentro do Videobrasil, com sucessivas participações e premiações, Santos é convidado a dirigir a décima edição do festival, quanto apresenta na mostra competitiva o vídeo "Janaúba" (1993), em que procura, em vez de atacar a banalização do audiovisual, "recuperar alguma espécie de energia primordial das artes visuais, ou restabelecer o sentido e a força das imagens, que se teriam perdido no atual oceano de imagens industriais" (MACHADO, 2007, p. 44).

Janaúba é inspirado no filme "Limite" (1930) de Mário Peixoto e recria a cena

10 Trecho de autoria do artista retirado do site Videobrasil, link de acesso: http://site.videobrasil.org.br/acervo/obras/obra/96126 
clássica dos personagens a bordo de um barco que chega vagarosamente por um rio. O vídeo faz menção ao nome do filme, por meio do poema/texto que é contido no vídeo, de autoria de Marcus Vinícius do Nascimento:

Tem o limite / Tem o limite que o tempo de vida útil limita / e começa a se contrair mais ainda puxando o lençol da superfície do mundo. / Tem o limite que o tempo de vida útil limita / esfolando a terra que arde / tem o limite que o tempo de vida útil limita / e acaba num toco de madeira estorricado / tem o limite / o erro nas estórias / o erro nas estórias é atentar o demônio da estrada / o demônio da estrada não quer parte com estranhos / o demônio da estrada não quer parte com estranhos / só ficar consumindo espíritos ensimesmados / o demônio da estrada não quer parte com estranhos / só ficar consumindo espíritos ensimesmados / que acham que vão longe / queimação dos infernos / depois de horas remoendo os porquês das dores incessantes / depois de horas remoendo os porquês das dores incessantes / pegação sem motivo, sem amor perfeito demais que tome conta de toda a vida / tem o limite e tem o carro de boi / tem o limite e tem o carro de boi / que na parte baixa do mundo é mais afastado de Deus / por isso é que a ponta do chifre dos ruminantes não alcança o limite / tem o limite a um palmo / um palmo é a medida do visível / dado que amores quase cegos têm pouco alcance ${ }^{11}$.

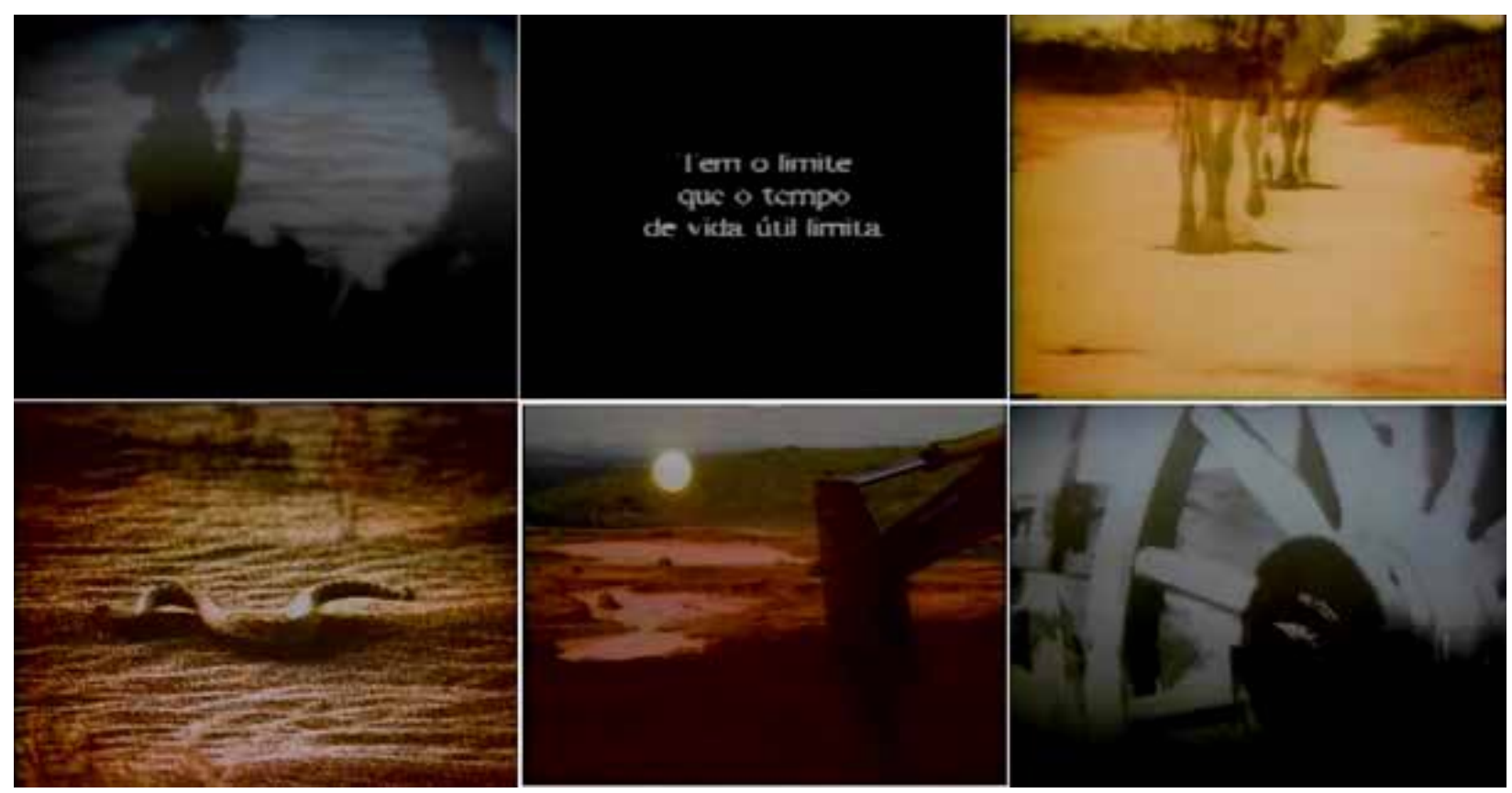

Figura 07 - Frames do vídeo "Janaúba", Eder Santos, 1993.

Fonte: Print do vídeo https://www.youtube.com/watch?v=SAMmRcBQ_Co

Nesse vídeo, Santos reutiliza imagens captadas do Death Valley (EUA), como a cena da cobra se arrastando pela areia do deserto (Figura 39), e trata, principalmente, em sua narrativa poética, da questão da vida no interior, uma vez que o nome da obra Janaúba se refere a uma pequena cidade mineira. O poema/texto manifestado no vídeo em linguagem escrita concede toda a confluência da temática, agregando um sentido narrativo junto às imagens e tecendo sobre a liquidez do tempo e a vida útil imposta a tudo e todos, o que nos induz a pensar nos limites que nos são colocados. Versa sobre a mesmice cotidiana e os hábitos que nos impedem de avançar, estag-

11 Texto/poema extraído do vídeo Janaúba (1993), autoria de Marcus Vinícius do Nascimento. Link para acesso do vídeo: https://www.youtube.com/watch?v=SAMmRcBQ_Co 
nando tudo, percorrendo e remoendo os mesmos fracassos. Essa obra, além de ganhar como melhor vídeo no décimo Videobrasil, também ganha uma menção honrosa no V Festival Internacional de Vídeo, em Vigo, na Espanha (SANT'ANNA, 2010).

Santos, em abril de 1996, viria a ser o primeiro brasileiro a apresentar uma videoinstalação no World Wide Video Festival, que acontecia na cidade de Haia, na Holanda ${ }^{12}$. A videoinstalação, "O Lago e a Montanha" (1996) foi composta por quatro laser videodiscos, cinco projetores de vídeo, dois amplificadores, quatro caixas de som, um lago artificial e uma montanha artificial, como exemplificado na Figura 40. O áudio, sendo dois situados atrás da montanha e dois à margem do lago, reproduzia diferentes ambientações: uma para o lago e outra para a montanha.

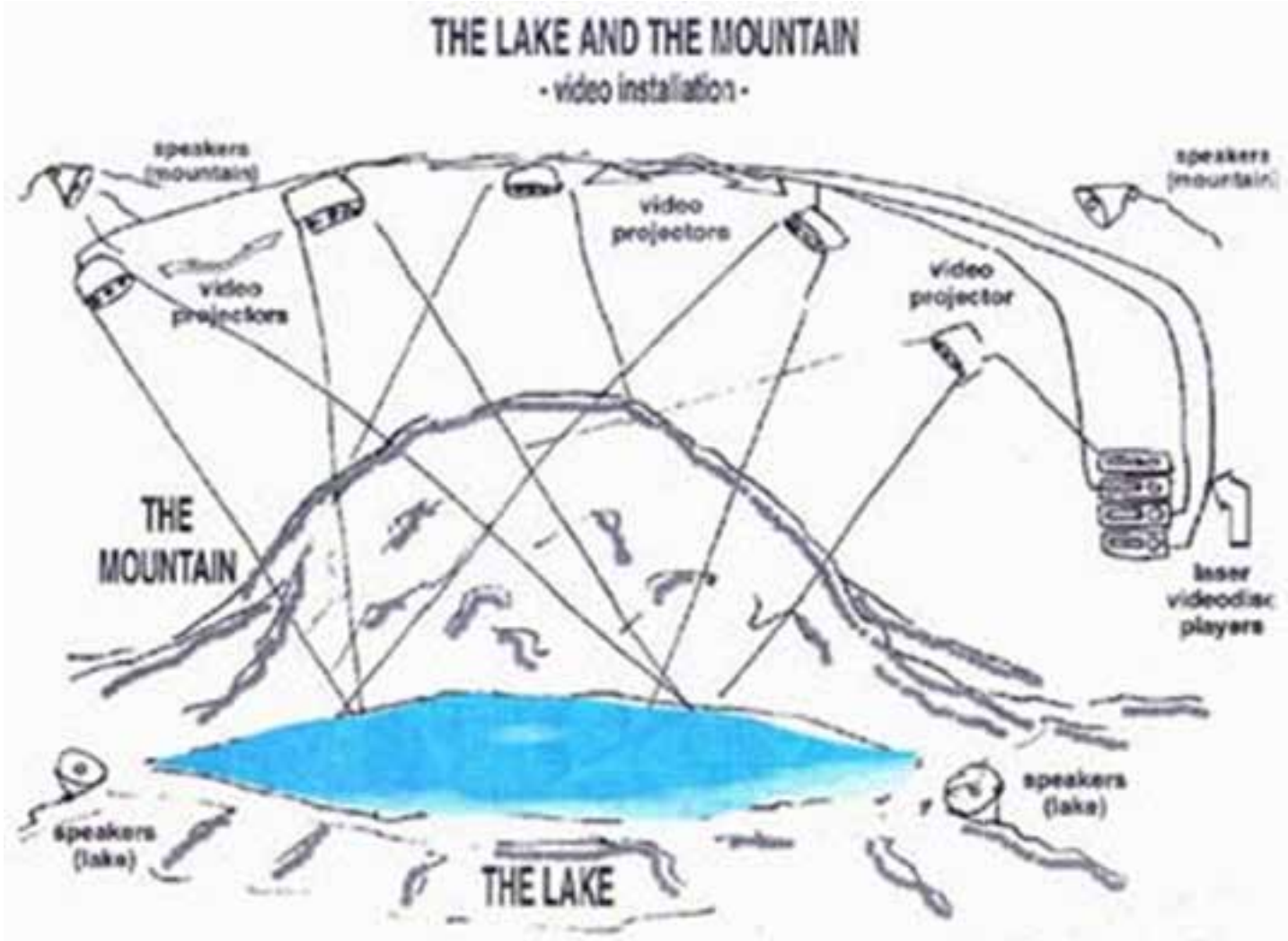

Figura 08 - Projeto da videoinstalação "O Lago e a Montanha", Eder Santos, 1996 Fonte: Site $23^{a}$ Bienal Internacional de São Paulo http://www.23bienal.org.br/universa/pubres.html

Segundo o artista, que criou o próprio texto curatorial, as imagens:

[...] se transmutam pela superfície de projeção, o cinema escolhe a grande tela para mostrar as riquezas da profundidade ótica da lente fotográfica. A profundidade de campo das imagens do cinema se contrapõe à imagem plana do vídeo. As imagens foram confinadas a espécies de cartões postais que recortam e reduzem paisagens tornando-as simples trechos desordenados dentro da confusão informativa da era da reprodutibilidade técnica.

A TV (monitor), no caminho de seus elétrons, explode irradiando à visão dos homens a imagem plana das redes de comunicação mundial.

A proposta da projeção de imagens em suportes como a montanha e o lago tentam recuperar a contemplação da paisagem, tentam trazer de volta a experiência orgânica da observação. Contando com esses propósitos típicos da cultura oriental, o I Ching - livro das mutações - surge como elemento que se soma à mutabilidade das imagens e da superfície - montanha e lago. (SANTOS, 1996). 
A presença de Santos em um festival dessa magnitude compondo uma obra de destaque em seu espaço, repercute de várias formas tanto no exterior, pois se tratava de um festival que era local de encontro de muitos agentes da arte, quanto no Brasil. Segundo Carlos Henrique Santiago (1996), da agência do Folha de S. Paulo de Belo Horizonte, o festival da Holanda, que aconteceu no Museu de Haia, contou com a presença de Catherine David, então diretora da "Documenta X", de Kassel (Alemanha). Através da notícia anunciada por Santiago (1996) no Brasil, podemos constatar a visibilidade que alcançaria.

\section{Inserção em circuitos artísticos tradicionais no Brasil}

O artista percorre um caminho inverso ao ser reconhecido no ambiente das artes plásticas no Brasil. Primeiro circula por mostras em grandes museus e festivais estrangeiros, para posteriormente participar de exposições artísticas brasileiras. De acordo com o artista, ele passa a ficar mais conhecido no meio das artes plásticas após participar do projeto Arte-Cidade, de intervenções urbanas na cidade de São Paulo, criado pelo filósofo e curador Nelson Brissac Peixoto, que teve início em 1994, sendo concluído em 2002.

Ao todo o projeto se apresentou por meio de quatro exposições, tendo as duas primeiras ocorridas em 1994, nomeadas de "Cidade sem Janelas" e "Cidade e seus Fluxos". A primeira exposição, a qual Eder Santos fez parte, "Cidade sem Janelas", ocupou o edifício abandonado do Matadouro Central da Vila Mariana, e a segunda aconteceu em três edifícios e no espaço público do Vale do Anhangabaú. A terceira mostra, de 1997, "A Cidade e suas Histórias", teve como cenário a estrada de ferro da cidade, ocupando ainda dois parques industriais abandonados. A última, "Arte/Cidade Zona Leste" conclui-se em 2002 e interveio em vários locais na zona leste paulista, contando com muitos artistas estrangeiros em sua participação (PEIXOTO, 2013).

A primeira mostra contou com a participação de quinze $\operatorname{artistas}^{13}$, dentre eles, Eder Santos. Segundo Nelson Brissac Peixoto, os galpões do antigo matadouro:

[...] abrigam um mundo subterrâneo e sombrio. Um espaço desprovido de memória, do qual só restam a estrutura fabril e resquícios mecânicos da atividade esquecida. As grossas paredes de tijolos, as vigas de ferro, as portas e janelas cerradas exercem um peso opressor. Universo maquinal marcado pela corporeidade, onde o arado fende a terra e a alavanca move as engrenagens. Esforço humilde contra um mundo coagido pela força da gravidade. Ao oposto do impulso contemporâneo à transparência e leveza, à tentativa de evitar a compacidade do mundo pelas torres e arranha-céus, temos um confronto direto com o volume esmagador da matéria. Os artistas aqui reunidos atuam sobre a espessura das coisas. Em vez de uma expectativa de transcendência, eles olham para baixo, para o que tem densidade e concretude, o que puxa para o chão (PEIXOTO, 2013).

Em um espaço interno do matadouro, Santos projeta três vídeos em superfícies irregulares de terra (Figura 09), nomeando a obra de "Trem de Terra" (1994). As imagens projetadas foram filmadas da janela de um trem em movimento, causando um

13 Os artistas participantes da mostra "Cidade sem Janelas", são: André Klotzel, Annemarie Sumner, Antonio Saggese, Arnaldo Antunes, Arthur Omar, Carlos Fajardo, Carmela Gross, Cássio Vasconcellos, Eder Santos, Enrique Dias, Jorge Furtado, José Resende, Livio Tragtenberg, Marco Giannotti, e Susana Yamauchi. (PEIXOTO, 2013) 
efeito de movimento em um local imóvel, em que tudo passa rapidamente, sem sair do lugar. Sobre as três imagens projetadas, Ismail Xavier constata que:

É nítida a subjetivação do olhar pelo constante movimento de câmera-na-mão que explora texturas. Na oscilação, portanto, entre o explorar geometrias com disciplina e o construir este olhar-projeção de um sujeito, as três imagens de Eder retomam pesquisas da vanguarda dos anos 20: franquear os limites da percepção, fazer ver o que não se oferece ao olhar desarmado, tencionar o campo do visível, questionar o senso comum e convidar a uma nova vivência da cidade. $\mathrm{O}$ nervosismo das imagens assinala uma dinâmica que nos ultrapassa. E o desconcerto faz desta itinerância do olhar não bem uma flanerie mas o enfrentamento de uma opacidade radical. (XAVIER, 2013).

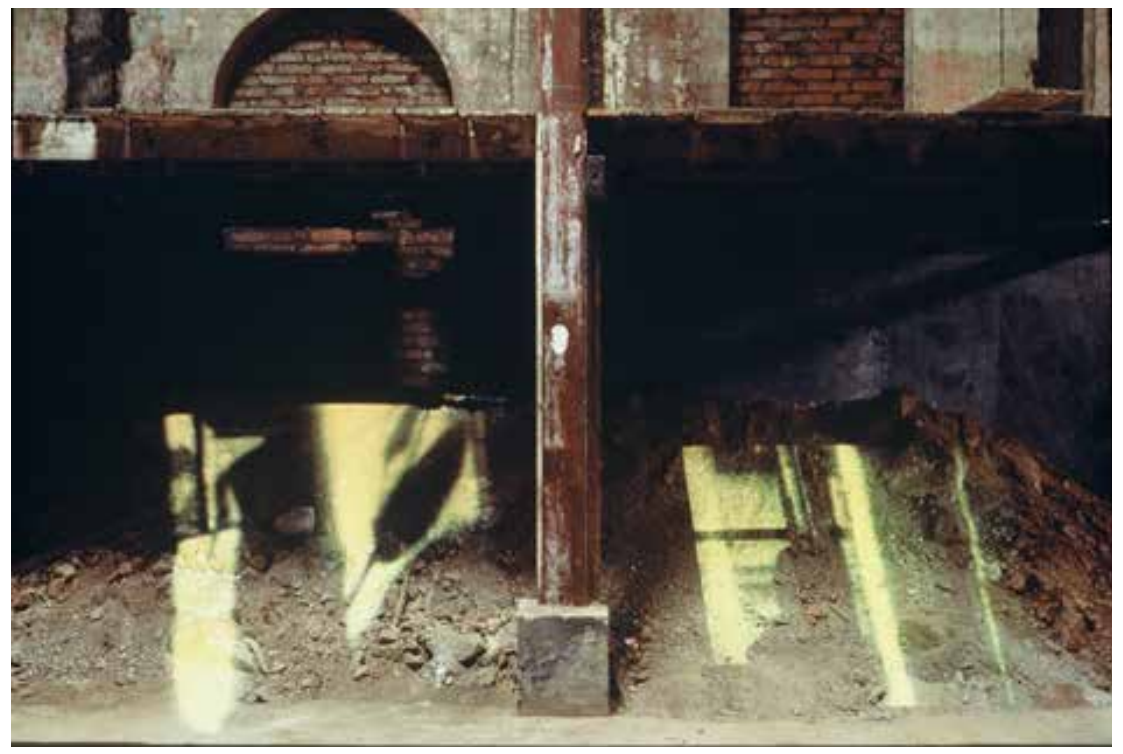

Figura 09 - Trem de Terra, Projeto Arte-cidade/Cidade sem Janelas, Eder Santos, 1994. Fonte: https://www.artecidadelinhametalica.org/anteriores/

Após a participação nesse projeto, criado na gestão de Ricardo Ohtake enquanto Secretário da Cultura do Estado de São Paulo (1992-1994), Santos viria a ser convidado a integrar uma mostra tradicional do Museu de Arte Moderna de São Paulo, "Panorama da Arte Brasileira", realizada desde 1969. Nessa mostra, que ocorreu de outubro a novembro de 1995, houve a reinauguração do museu, que se encontrava fechado por dois meses para reformas. Nela, Santos integrou o "Programa de artista" com o vídeo Janaúba (1993), ao lado do artista multimídia gaúcho Rafael França (1957-1991). Nessa exposição, participaram importantes nomes da arte brasileira, tal qual Cildo Meireles, Arthur Omar, Miguel Rio Branco, entre outros. A presença na mostra foi importante para dar visibilidade ao trabalho de Santos no circuito artístico tradicional, agregando significante valor em sua trajetória e reconhecendo de forma simbólica o suporte com o qual o artista trabalha.

No ano seguinte, em 1996, Santos seria convidado a integrar a mostra Universalis/Brasil, um segmento da XXIII Bienal Internacional de São Paulo, curada por Nelson Aguilar e Agnaldo Farias. A proposta desse segmento foi repartir o globo em sete macrorregiões (Brasil, África/Oceania, América Latina, América do Norte, Ásia, Europa Ocidental, Europa Oriental), confiando a curadores eleitos para cada delas o trabalho em selecionar de cinco a sete artistas para representar esse mundo artístico 
com o que havia de mais emergente e singular, em um momento em que as identidades nacionais se liquefizeram com o processo de globalização (CANCLINI, 1997).

Em Universalis/Brasil, seis artistas foram selecionados por Aguilar e Farias para representar o país, o já citado Eder Santos, mais, Arthur Barrio, Geórgia Kyriakakis, Nelson Felix, Flávia Ribeiro e Roberto Evangelista. Dentre a multiplicidade de formas e poéticas particulares de artistas brasileiros, Agnaldo Farias firma a proposta da mostra:

\footnotetext{
Tal como foi concebida, a mostra Universalis tenta estabelecer um campo de discussão sobre esse estado de coisas que caracteriza a vida contemporânea. O fato de haver elegido como tema o processo de desmaterialização pelo qual vem passando a obra de arte há pelo menos 30 anos serve para aprofundar ainda mais o debate. Do mesmo modo, o convite efetuado a seis outros curadores, cada qual ligado a uma região do planeta, tem como finalidade demonstrar como um mesmo problema, além de suscitar leituras variadas, irrompe, como é o caso, em diferentes poéticas, cujas especificidades justificam-se pelo modo como cada uma delas se inscreve em circunstâncias históricas bem definidas, dentro de um horizonte ideológico que lhe é particular, ou ainda, dito à luz de Guimarães Rosa, que se desenvolve a partir de margens singulares. (FARIAS, 1996).
}

Santos expôs na Bienal a videoinstalação "Memória de Ferro" (1996) - que dá nome ao presente texto -, em que utilizou para compô-la dez toneladas de minério de ferro trazidas de Minas Gerais, três vídeo-discos, três projetores de vídeos, três telas de seda, espelhos, som ambiente e iluminação especial. Fazendo o espectador caminhar pelo chão irregular e confrontando-o frente a espelhos, onde projetada a imagem em vídeo de uma mulher, sugere aos participantes uma presença virtual, criando um contato fictício entre o eu e o outro. A projeção virtual da mulher sugere uma presença fantasmática, em que simula, no ambiente da instalação, um deslocamento da história das minas de ferro. A sua presença fantasmática parece incorporar o sentido de um passado histórico das Minas Gerais, de exploração e colonização. Como o nome da obra já insinua, "Memória de Ferro" faz uma metáfora da memória desse passado árduo, de uma sociedade que não esquece a sua história tão facilmente. Uma memória resistente que não irá relegar ao esquecimento.

Ainda de forma a ver seu crescimento em confluência com o Festival Videobrasil, nesse mesmo ano, 1996, o artista integraria o júri da décima primeira mostra, que homenageia Nam June Paik, designado pelo evento como o pai da videoarte. Foram exibidas quatro instalações e duas mostras retrospectivas da obra single channel de Paik, cobrindo o período de 1969 a 1995. Nesse ano, além de integrar o júri, Santos, comissionado novamente pelo festival, exibe a instalação/performance com projeções de imagens em vídeo e música eletrônica, intitulada "Passagem de Mariana" (1996), em que revisita os sete pecados capitais em uma parceria com Paulo Santos e o grupo UAKTI.

\section{Conclusão}

Dentre as frequentes participações de Santos em circuitos alternativos de exibição de vídeos, vemos a extensão de festivais do mundo inteiro para circuitos artísticos tradicionais, que ocorreram acentuadamente na segunda metade da década de 
1990. Desde então, Eder Santos vem sido recorrentemente reconhecido como um dos maiores produtores de arte multimídia do Brasil, com uma extensa produção que tem o vídeo como suporte principal de suas criações. Na virada para o século XXI, o artista já viria a realizar as primeiras exposições individuais, em espaços no Brasil como o Palácio das Artes e o Museu da Pampulha, em Belo Horizonte, a Galeria Brito Cimino (uma das galerias que representa suas obras ${ }^{14}$ ), em São Paulo, o Museu de Arte Moderna da Bahia, em Salvador, os Centros Culturais Banco do Brasil, de Brasília e do Rio de Janeiro, entre outros espaços.

Sobre os CCBBs - onde as exposições individuais de Santos foram realizadas em 2009, ambas intituladas Galeria das Almas/Altar das Virgens - Nei Vargas da Rosa destaca que sua política "privilegia propostas com forte apelo de marketing, decisão que excluiu da grade de programação projetos para artistas em início de trajetória em detrimento de exposições com artistas consagrados" (2014, p. 61). Tal fator é apresentado pelo autor como muito problemático, pois ao retirar artistas iniciantes da sua grade de exibições, consequentemente produtores culturais e curadores em início de trajetória também acabariam prejudicados, pois dificilmente um artista consagrado iria associar seu nome a produtores e curadores com pouca experiência no mercado (ROSA, 2014). A escolha por elucidar tal fator, é apenas para firmar o reconhecimento que Santos como artista viria a atingir nos anos 2000.

Com muitas exposições realizadas tanto no Brasil quanto fora dele, pudemos associar o crescimento artístico de Eder Santos ao transpassar o espaço fechado da tela da TV para compor ambientes participativos e sensoriais com projeções de imagens. Tais ambientes, ou videoinstalações, foram essenciais para se fazer reconhecer no meio das artes plásticas convencionais e esse desenvolvimento deve muito ao apoio que o Videobrasil forneceu, dando espaço e financiando seus projetos.

Eder Santos, recém-chegado no campo como videoartista, pôde fazer carreira através do Videobrasil e encontrou ali um espaço e apoio profícuo para a criação e desenvolvimento de suas obras. Vimos a sua passagem do vídeo single channel para a construção de ambientes com projeções e diversos outros materiais, alcançando grandes dimensões. Através de sua primeira grande videoinstalação, "The Desert in My Mind" (1992), comissionada e exibida pelo Videobrasil, Santos ganha visibilidade por sua obra trabalhar importantes questões do contexto da arte contemporânea. Assim, aos poucos passa a ser inserido em projetos curatoriais no Brasil, como o Arte/ Cidade (1994), proposto por Nelson Brissac Peixoto, que abriu portas para integrar outras proposições, como a 23aㅡ Bienal Internacional de São Paulo, de 1996. Tais projetos, foram importantes para agregar valor simbólico a sua carreira artística e fizeram com que fosse reconhecido nesse universo.

Em suma, o artista, que inicia sua carreira participando de circuitos alternativos de exibição de vídeo, passa de um reconhecimento pelo suporte para uma imersão ampla no universo da arte contemporânea mundial, inserindo-o em projetos curatoriais, que se definem a partir de eixos conceituais ou de linguagens. Deixa de ser reconhecido em função do suporte e da mídia específica, passando a se reconhecer como artista contemporâneo e multimídia. Após receber o bilhete de entrada para transitar

14 A outra galeria que representa as obras de Eder Santos é a Galeria Celma Albuquerque, de Belo Horizonte 
nesse universo, que lhe confere capital simbólico, o artista sai de um contexto específico de linguagem e suporte para adentrar e integrar um todo geral.

\section{Referências Bibliográficas}

ANDRADE, C. D. Obra Poética. Rio de Janeiro: Aguillar, 1993.

ÁVILA, C.; GOMES, M. C. A. O negro no Barroco Mineiro: O caso da Igreja do Rosário de Ouro Preto. Revista do Departamento de História, Belo Horizonte, n. 6, jun. 1988. pp. 69-76

BUENO, M. L. Fluxo e contrafluxos. In: (Catálogo) Rede de Tensão. São Paulo: Imprensa Oficial do Estado; Paço das Artes, 2001. pp. 80-84

CANCLINI, N. G. Culturas híbridas: estratégias para entrar e sair da modernidade. São Paulo: Edusp, 1997.

CARVALHO, V. Dispositivo e experiência: relações entre tempo e movimento na arte contemporânea. Revista Poiésis, n.12, nov. 2008. pp.39-50

CRUZ, R. M. Imagens projetadas: Projeções audiovisuais e narrativas no contexto da arte contemporânea. Tese de Doutorado. Programa de Pós-Graduação em Comunicação e Semiótica da Pontífica Universidade Católica de São Paulo; 2010.

DUGUET, A. M. Déjouer l'image: Créations électroniques et numériques. Nîmes: Éditions Jacqueline Chambon, 2002.

FARIAS, A. Apresentação: Notas a margem. In: FBSP. Universalis: Catálogo. São Paulo: FBSP, outubro/dezembro, 1996.

FILHO, A. G. “Videobrasil cria deserto no Sesc Pompéia. Folha de S, Paulo, São Paulo, 23 set. 1992.

FOSTER, H. Este funeral es por el cadáver equivocado. In: Diseño y delito. AKAL, 2004. pp. $123-169$

HUYSSEN, A. Culturas do passado-presente: modernismos, artes visuais, políticas da memória. Rio de Janeiro: Contraponto: Museu de Arte do Rio, 2014.

JESUS, E. Imagens que Deslizam. In: SANTOS, E. Eder Santos: Depoimento. Entrevista e Organização: RIBEIRO, M. A. Belo Horizonte: C/ Arte, 2010. pp. 03-05

JUNIOR, G. B. "Eder Santos ultrapassa os limites do monitor". O Estado de S. Paulo, São Paulo, 13 mar. 1996. 
JÚNIOR, M. A. O conceito de ruína e o dilema da conservação em arte contemporânea. Revista ARA, n.2, Grupo Museu/Patrimônio FAU-USP, outono/inverno, 2017. pp.133-157

MACHADO, A. As linhas de força do vídeo brasileiro. In: MACHADO, A. (Org.). Made in Brasil: Três décadas de vídeo no Brasil. São Paulo: Ed. Iluminuras, 2007. pp.15-47

. Pré-cinemas \& pós-cinemas. São Paulo: Papirus, 1997.

PARENTE, A. Cinema de exposição: o dispositivo em contra-campo. Revista Poiésis, n.12, nov. 2008. pp.51-63

PEIXOTO, N. B. Cidade sem janelas. In: PEIXOTO, N. B. Intervenções urbanas: Arte/ Cidade. São Paulo: Edições Sesc/Editora Senac, 2013.

RIBEIRO, M. A (Org.). Eder Santos: Depoimento. Belo Horizonte: C/ Arte, 2010.

ROSA, N. V. O estado e o empresariamento do Sistema da arte. In: BULHÕES, M. A. (Org.). As novas regras do jogo: o sistema de arte no Brasil. Porto Alegre: Zouk, 2014. pp. $45-76$

SANT'ANNA, S. M. Cronologia. In: RIBEIRO, M. A (Org.). Eder Santos: Depoimento. Belo Horizonte: C/ Arte, 2010. pp.85-91

SANTIAGO, C. H. "Videoinstalação de Éder Santos é exibida na Holanda". Folha de S. Paulo, São Paulo, 30 abr. 1996.

SANTOS, E. Depoimento. In: RIBEIRO, M. A (Org.). Eder Santos: Depoimento. Belo Horizonte: C/ Arte, 2010. pp.09-38

Depoimento. In: NAGIB, Lúcia. O cinema da retomada: Depoimentos de 90 cineastas dos anos 90. São Paulo: Ed. 34, 2002. pp. 431-434

O lago e a montanha. In: FUNDAÇÃO BIENAL DE SÃO PAULO. Universalis: Catálogo. São Paulo: FBSP, outubro/dezembro, 1996.

VIDEOBRASIL, A. C.; SESC SP, S. S. C. Videobrasil: Três décadas de vídeo, arte, encontros e transformações. São Paulo: Sesc SP: Videobrasil, 2015.

XAVIER, I. As figurações do tempo. In: PEIXOTO, Nelson Brissac. Intervenções urbanas: Arte/Cidade. São Paulo: Edições Sesc/Editora Senac, 2013.

\section{Catálogos}

VII FESTIVAL FOTOPTICA VIDEOBRASIL, 1989. 


\section{Vídeos Consultados}

DEPOIMENTO | 30 ANOS | SOLANGE FARKAS. Link de acesso: https://vimeo.com/ album/2630179/video/87182638

VB na TV | 30 ANOS | PGM1. Link de acesso: https://vimeo.com/79307406 